\title{
Virtual water content for meat and egg production through livestock farming in Saudi Arabia
}

\author{
Shakhawat Chowdhury ${ }^{1}$ (D) Omar K. M. Ouda ${ }^{2} \cdot$ Maria P. Papadopoulou $^{3}$
}

Received: 27 April 2017/ Accepted: 9 October 2017/Published online: 19 October 2017

(c) The Author(s) 2017. This article is an open access publication

\begin{abstract}
The concept of virtual water content (VWC) may facilitate an understanding of total water demand for commodity production. The water consumption for livestock production forms a significant fraction of freshwater demand in arid regions, i.e., Saudi Arabia. In this paper, VWC was estimated for different livestocks in the 13 regions of Saudi Arabia. The VWC for camel production was also estimated, which has not been investigated in the previous studies. The overall VWC for livestock in Saudi Arabia was about 10.5 and 8.9 billion $\mathrm{m}^{3}$ in 2006 and 2010, respectively. This study shows the decreasing trend of overall VWC in producing livestock in Saudi Arabia. The VWC were highest in Riyadh followed by Eastern region, Qaseem, Hail, and Makkah with ranges of 3587-4112, 1684-2044, 1007-1331, 644-810, and 504-715 million $\mathrm{m}^{3} /$ year, respectively. The results demonstrate that a shift in diet from the high VWC meat to low VWC meat may reduce the overall VWC for livestock
\end{abstract}

Shakhawat Chowdhury

SChowdhury@kfupm.edu.sa

Omar K. M. Ouda

oouda@pmu.edu.sa

Maria P. Papadopoulou

mpapadop@mail.ntua.gr

1 Department of Civil and Environmental Engineering, King Fahd University of Petroleum and Minerals, Dhahran 31261, Saudi Arabia

2 Civil and Environmental Engineering Department, Prince Mohammad Bin Fahd University, Al-Khobar 31952, Saudi Arabia

3 School of Rural and Surveying Engineering, National Technical University of Athens (NTUA), 9 Heroon Polytechniou, University Campus, Zografou, 15780 Athens, Greece production. The findings of this analysis provide an assessment of the quantity and trend of water demand for livestock production in Saudi Arabia, which is useful to assess the development of an information-based agricultural water management strategy.

Keywords Virtual water content - Water saving - Water resources management · Arid region · Livestock farming · Water demand

\section{Introduction}

The agricultural sector uses the largest share of freshwater resources worldwide. The average worldwide freshwater consumption per person was about $1385 \mathrm{~m}^{3}$, of which agriculture, industry and domestic use consumed about 91 , 5, and 4\%, respectively (Ouda 2014). In the Middle East, agriculture accounts for over $75 \%$ of total water consumption. However, with increasing demand resulting from population growth coupled with higher living standards, water will be reallocated away from the agriculture sector to the domestic and industrial sectors (Karrou et al. 2011; Ouda 2014). A rational water resource management plan (WRMP) requires the estimate of direct and indirect consumptions of water. The concept of water footprint (WFP) has been increasingly used as an indicator of water consumption and it is an informative tool for comprehensive understanding of water demand at national level (Hoekstra 2003; Chapagain and Hoekstra 2003; Charchousi et al. 2015). Past studies reported that the major fractions of WFP were due to the agricultural and industrial consumptions, while agriculture consumed more than $80 \%$ of global freshwater supplies (Shiklomanov 2000; Mekonnen and Hoekstra 2011). Almost $30 \%$ of the global agricultural 
WFP was related to livestock animal production (Mekonnen and Hoekstra 2012). The WFP of many animal products is larger than the WFP of crop products with equivalent calorie value (Mekonnen and Hoekstra 2012). The average WFP per calorie for beef was 20 times larger than for cereals and starchy roots, while the WFP per gram of beef protein was 6 times larger than for pulses (Mekonnen and Hoekstra 2012). Earlier study reported that by replacing all meat with an equivalent amount of crop products, a $30 \%$ reduction of the food-related WFP per American citizen could be obtained (Mekonnen and Hoekstra 2012). However, there are several animal products, which have lower WFP than crop products when nutritional value is considered. The worldwide meat production has been projected to be double by 2050 in the developing countries, due mainly to the increase in production and consumption (IAASTD 2008; Steinfeld et al. 2006; Alexandratos and Bruinsma 2012; Ran et al. 2016), which is likely to intensify the freshwater crisis in the future (Rost et al. 2008; Ran et al. 2016).

An information-based water management strategy can support the development of an optimal management plan to reduce water demand-supply gap, especially in arid and semi-arid regions, such as Saudi Arabia. The development of an optimal WRM plan requires comprehensive understanding of water demand pattern, supply system, and the estimate of water quantities and trends (Allan 1997). The analysis of virtual water content (VWC), which is closely linked to WFP, provides an information-based understanding of water demand for agricultural commodities, including livestock production (Hoekstra and Chapagain 2007; Mekonnen and Hoekstra 2012; Gerbens-Leenes et al. 2013). Virtual water is defined as the volume of water required to produce a commodity or a service. This concept was first introduced when the option of importing virtual water (coming along with food imports) was examined as a partial solution to water scarcity problems in the Middle East countries (Allan 1993, 1994, 1997). To assess the national WFP, it is essential to quantify the VWC for the products that are produced and consumed locally in addition to the imported or exported VWC of the products that are leaving and entering a country (Hoekstra and Chapagain 2007). Quantification of VWC for the livestock production plays an important role in understanding the aspects of national WFP in Saudi Arabia. The livestock animal specific VWC identifies the type of animal responsible for greater fractions of water demand and thus provides an opportunity to optimize water use in livestock farming.

The water consumption of agricultural products used as feed items forms the major fractions of VWC for livestock farming (Rost et al. 2008; Mekonnen and Hoekstra 2012; Ran et al. 2016). The WFP of an agricultural product is defined as the sum of the blue, green, and grey WFP (Mekonnen and Hoekstra 2011). The blue WFP refers to water consumption from surface and groundwater sources, and green WFP refers to consumption of green water resources (e.g., rainwater in so far as it does not become run-off). The grey WFP refers to pollution and is defined as the volume of freshwater required to assimilate the load of pollutants given natural background concentrations and existing ambient water quality standards. Worldwide, green water contributes about $80 \%$ of the consumptive water use (CWU) in agricultural production (Molden et al. 2010; Rockström et al. 2014). In livestock production, green water accounts for $90 \%$ of total CWU (Mekonnen and Hoekstra 2012), while only $2-8 \%$ of CWU is blue water used for drinking water, servicing, and feed mixing purposes (Steinfeld et al. 2006; Mekonnen and Hoekstra 2012; de Boer et al. 2013; Ran et al. 2016). In Saudi Arabia, there is no natural surface water flow system and the countrywide average annual rainfall is very low (<70 mm/year) (Chowdhury and Al-Zahrani 2013; AlZahrani et al. 2015). The soil moisture content is low and evaporation rate is extremely high (Missimer et al. 2014). As a result, the contribution of green water to agricultural crop production is minimal (MOWE 2013; Chowdhury et al. 2016). The only dependable source of water for crop production is groundwater pumped from the non-renewable aquifers, which represented the blue water (MOWE 2013; USDA 2016). The agricultural farms typically pump the groundwater for irrigation (Chowdhury et al. 2016).

Different types of meat (e.g., camel, cow and dairy cow, goat, poultry) and egg are produced through the in-house and open grazing farming in Saudi Arabia (SSYB 2011). The VWC for these livestock products varies depending on the climatic conditions, the region and the applied farming practices. For example, Chapagain and Hoekstra (2003) predicted the VWC for 1 ton of beef and poultry meat in Saudi Arabia as 11,359 and $4146 \mathrm{~m}^{3}$, respectively. In Egypt, these values were 15,752 and $2268 \mathrm{~m}^{3} / \mathrm{ton}$, respectively while in Germany, these were 7768 and $877 \mathrm{~m}^{3} /$ ton, respectively. The differences in VWC were related to production efficiency, including the genetic merit of animals and farming management practices. For example, the lower value of VWC for beef in Germany was due to higher growth rate than in Saudi Arabia. In Saudi Arabia, climatic variability between the northern and southern regions is significant, which affects VWC of livestock farms. Furthermore, farming practices and feed consumptions are likely to be variable. In addition, the country produces a large amount of camel meat, while camel is not the typical livestock in most countries, and the VWC for camel has seldom been investigated (Chapagain and Hoekstra 2003). As a result, data on VWC presented in the previous studies do not reflect the major livestock animals 
and farming practices applied in Saudi Arabia (Chapagain and Hoekstra 2003; Mekonnen and Hoekstra 2010, 2011, 2012). Better understanding of VWC for livestock animals and egg production in different regions of Saudi Arabia is highly needed to guide the allocation of livestock farming and optimize water use.

The total water demand in Saudi Arabia was increasing for the last few decades, due mainly to the rapid population growth and urbanization, and the expanded agricultural activities (World Bank 2010; UNDP 2013). In 2010, the gap between water demand and sustainable water supply was about 11.5 billion $\mathrm{m}^{3}$ (UNDP 2013). The water demand-supply gap was bridged through extensive use of non-renewable groundwater resources, desalinated water, and minimal use of treated wastewater (UNDP 2013). The depletion of groundwater volumes threatens the sustainable development plan of the country and raises significant water security issues. To optimize the agricultural water demand and minimize the water demand vs. supply gap, the country has completely phased out wheat production in 2015 and there is a plan to phase out the production of fodder crop by 2019. No doubts, these two measures could be very effective. It is to be noted that the agriculture sector is the largest consumer of freshwater, in which the share of the livestock farms is significant (Al-Zahrani and Baig 2011; Al-Shayaa et al. 2012; Mekonnen and Hoekstra 2012).

The importance of VWC for livestock farms in Saudi Arabia has not been previously investigated. This study assesses the VWC for camel, cow, dairy cow, sheep, goat, poultry, and egg production in the 13 regions of Saudi Arabia. In this study, the regional variability of VWC in the country is examined. Finally, the analysis provides recommendations towards the development of an informationbased agricultural water management strategy that will optimize freshwater use in livestock industry by highlighting the limitations and future research needs.

\section{Methodology}

Saudi Arabia is divided into 13 administrative regions. The main farming animals are camel, cow (used for meat production), dairy cow (used for milk production), sheep, goat, and poultry. In addition, a large number of hens (used for eggs) are also produced. The livestock production analysis was based on data for the period of 2006-2010 (Table 1) obtained from the Saudi Statistical Yearbook (SSYB 2011). The details of productive animals and eggs for each year can be found in SSYB (2011). These data represent the total number of productive animals (e.g., slaughtered) and eggs (e.g., consumed) in the respective years. The feeding composition, style, and water consumption for these animals prior to achieving the slaughtering ages were obtained through field survey and were validated through data obtained from the literature (Chapagain and Hoekstra 2003; Abdallah and Faye 2013).

To calculate the VWC, the WFP methodology of Mekonnen and Hoekstra (2012) was followed. The WFP was predicted as

$$
\begin{aligned}
\mathrm{WFP}[\mathrm{a}, \mathrm{c}, \mathrm{s}]= & \mathrm{WFP}_{\text {feed }}[a, c, s]+\mathrm{WFP}_{\text {drink }}[a, c, s] \\
& +\mathrm{WFP}_{\text {service }}[a, c, s],
\end{aligned}
$$

where $\operatorname{WFP}[a, c, s]=\mathrm{WFP}$ for category $a$ animal in country $c$ for production systems $s$. $\mathrm{WFP}_{\text {feed }}[a, c, s]$, $\mathrm{WFP}_{\text {drink }}[a, c, s]$, and $\mathrm{WFP}_{\text {service }}[a, c, s]$ represent the WFP for category $a$ animal in country $c$ for production systems $s$ related to feed, drinking water, and service water consumption purposes, respectively. In the current study, VWC was predicted in one country ( $c=1$ : Saudi Arabia) for seven categories of farm products $(a=i=1,2, \ldots .7$, representing camel, cow, dairy cow, sheep, goat, poultry, and egg) following one production system ( $s=1$ : mixed type). It should be noted that animal feed items are originated from domestic and imported products. To calculate the WFP for the feed items, Mekonnen and Hoekstra (2012) used the weighted average WFP for the domestic and imported products. The weighted average WFP was calculated as

$\mathrm{WFP}^{*}[p]=\frac{P[p] \times \operatorname{WFP}[p]+\sum_{\mathrm{n}_{\mathrm{e}}}\left(\mathrm{T}_{\mathrm{i}}\left[\mathrm{n}_{\mathrm{e}}, p\right] \times \operatorname{WFP}\left[\mathrm{n}_{\mathrm{e}}, p\right]\right)}{P[p]+\sum_{\mathrm{n}_{\mathrm{e}}}\left(T_{i}\left[\mathrm{n}_{\mathrm{e}}, p\right]\right)}$,

where $\mathrm{P}[p]=$ domestic production of feed item $p$ (ton/ year); $\mathrm{T}_{\mathrm{i}}\left[\mathrm{n}_{\mathrm{e}}, p\right]=$ imported amount of feed item $p$ (ton/ year) from exporting country $\mathrm{n}_{\mathrm{e}} ; \mathrm{WFP}[p]=$ WFP of feed item $p$ for domestic production $\left(\mathrm{m}^{3} / \mathrm{ton}\right) ; \mathrm{WF}\left[\mathrm{n}_{\mathrm{e}}\right.$, $p]=\mathrm{WFP}$ of feed item $p$ for exporting country $\mathrm{n}_{\mathrm{e}}$ $\left(\mathrm{m}^{3} /\right.$ ton $)$; and WFP* $[p]=$ weighted average WFP for feed item $p$ ( $\mathrm{m}^{3} /$ ton $)$. The calculation of weighted average WFP for a feed item requires the amounts of imported feed item from the exporting countries, WFP of this item in the source countries, domestic production of this item, and the amount of this item used for livestock farms to feed these animals (Mekonnen and Hoekstra 2012). At national level, this calculation can be performed through the use of country-specific imported feed amounts and WFP, and total domestic production and domestic WFP. However, at regional level within a country, it is often difficult to obtain precise information on these data. To minimize the complexity and information gap at regional level, this study distributes the imported feed items among the regions based on population distributions. The total population in the country was estimated to be 
Table 1 Summary of livestock production in Saudi Arabia (in million)

\begin{tabular}{|c|c|c|c|c|c|c|c|c|c|c|c|c|c|c|}
\hline \multirow[t]{2}{*}{ Region } & \multicolumn{2}{|l|}{ Camel } & \multicolumn{2}{|l|}{ Cow } & \multicolumn{2}{|c|}{ Dairy cow } & \multicolumn{2}{|l|}{ Sheep } & \multicolumn{2}{|l|}{ Goat } & \multicolumn{2}{|l|}{ Poultry } & \multicolumn{2}{|l|}{ Egg } \\
\hline & 2006 & 2010 & 2006 & 2010 & 2006 & 2010 & 2006 & 2010 & 2006 & 2010 & 2006 & 2010 & 2006 & 2010 \\
\hline Riyadh & 0.12 & 0.090 & 0.190 & 0.23 & 0.0729 & 0.1035 & 1.98 & 0.740 & 0.39 & 0.14 & 77.86 & 75.09 & 1096 & 1439 \\
\hline Makkah & 0.021 & 0.020 & 0.01 & 0.007 & 0.0000 & 0.0000 & 0.42 & 0.39 & 0.24 & 0.20 & 182 & 80.62 & 831 & 881 \\
\hline Madinah & 0.006 & 0.012 & 0.003 & 0.00 & 0.0000 & 0.0000 & 0.28 & 0.27 & 0.20 & 0.12 & 11.00 & 10.23 & 129 & 194 \\
\hline Qaseem & 0.034 & 0.020 & 0.015 & 0.016 & 0.0005 & 0.0004 & 1.23 & 0.721 & 0.13 & 0.05 & 132 & 138 & 505 & 580 \\
\hline Eastern region & 0.034 & 0.017 & 0.104 & 0.095 & 0.0270 & 0.0491 & 1.003 & 0.641 & 0.05 & 0.03 & 26.19 & 25.19 & 325 & 397 \\
\hline Aseer & 0.013 & 0.007 & 0.014 & 0.012 & 0.0000 & 0.0000 & 0.86 & 0.66 & 0.41 & 0.13 & 46.86 & 56.19 & 95 & 255 \\
\hline Tabouk & 0.003 & 0.001 & 0.003 & 0.003 & 0.0014 & 0.0014 & 0.063 & 0.043 & 0.08 & 0.05 & 3.49 & 4.67 & 59 & 67 \\
\hline Hail & 0.022 & 0.018 & 0.004 & 0.006 & 0.0030 & 0.0027 & 0.64 & 0.42 & 0.11 & 0.05 & 19.41 & 25.56 & 20 & 59 \\
\hline Northern region & & & & & 0.0000 & 0.0000 & 0.014 & 0.024 & & & 0.15 & 1.9 & & \\
\hline Jazan & 0.003 & 0.004 & 0.018 & 0.017 & 0.0000 & 0.0000 & 0.28 & 0.23 & 0.32 & 0.16 & 4.13 & 1.565 & & \\
\hline Nazran & 0.010 & 0.010 & 0.003 & 0.003 & 0.0009 & 0.0000 & 0.12 & 0.065 & 0.08 & 0.03 & 3.48 & 4.74 & 62 & 24 \\
\hline Al-Baha & 0.004 & 0.007 & 0.003 & 0.004 & 0.0000 & 0.0000 & 0.15 & 0.13 & 0.17 & 0.05 & 6.64 & 0.41 & 24 & 16 \\
\hline Al-Jouf & 0.010 & 0.006 & 0.002 & 0.000 & 0.0000 & 0.0000 & 1.06 & 0.891 & 0.08 & 0.04 & 2.04 & 1.58 & 16 & 74 \\
\hline Total & 0.284 & 0.213 & 0.368 & 0.390 & 0.1058 & 0.1571 & 8.091 & 5.231 & 2.253 & 1.06 & 515.3 & 425.8 & 3161 & 3987 \\
\hline
\end{tabular}

Empty cell no data due to very low numbers

around 27.1 million in 2010 (SSYB 2011; City population 2016), in which Makkah, Riyadh, Eastern region, Aseer, Madinah, Jazan, Qaseem, Tabouk, Hail, Najran, Al-Jouf, Al-Baha, and Northern region had 25.5, 25.0, 15.1, 7.1, 6.6, $5.0,4.5,2.9,2.2,1.9,1.6,1.5$, and $1.2 \%$ of the total populations, respectively. The imported feed items were distributed among these regions using the respective similar percentages (Table 2). Up on availability of region-specific production and source-specific import data for all feed items in a region, the WFP* calculations can be updated in future. Using the data equation (2) and following equation (1), the VWC can be estimated as

$\mathrm{VWC}_{i}=\mathrm{VWC}_{\text {feed }}+\mathrm{VWC}_{\text {drink }}+\mathrm{VWC}_{\text {service }}$

where $\mathrm{VWC}_{i}=$ virtual water content (VWC) for i category animal $\left(\mathrm{m}^{3} /\right.$ animal $), \mathrm{VWC}_{\text {feed }}=\mathrm{VWC}$ for feed consumed by an animal $\left(\mathrm{m}^{3} / \mathrm{animal}\right), \mathrm{VWC}_{\mathrm{drink}}=\mathrm{VWC}$ for drinking purposes $\left(\mathrm{m}^{3} /\right.$ animal), and $\mathrm{VWC}_{\text {service }}=\mathrm{VWC}$ for servicing/cleaning purposes $\left(\mathrm{m}^{3} / \mathrm{animal}\right)$. The VWC for feed was calculated based on the amount of feed consumed

Table 2 Weighted water footprint $\left(\mathrm{m}^{3} /\right.$ ton) (WFP*) for feed items used in Saudi Arabia

\begin{tabular}{|c|c|c|c|c|c|c|c|c|c|c|c|c|}
\hline & Riyadh & Makkah & Madinah & Qaseem & Eastern region & Aseer & Tabouk & Hail & Jazan & Najran & Al-Baha & Al-Jouf \\
\hline Wheat & 1123 & 1210 & 1070 & 951 & 965 & 849 & 944 & 851 & 1018 & 1142 & 1125 & 967 \\
\hline Oats & 2081 & 1122 & 2114 & 1533 & 1770 & 990 & 1385 & 1575 & 1690 & 1170 & 1185 & 1653 \\
\hline Barley & 669 & 835 & 555 & 444 & 718 & 610 & 539 & 704 & 496 & 679 & 564 & 548 \\
\hline Other grain & 533 & 441 & 481 & 456 & 631 & 454 & 481 & 552 & 558 & 468 & 357 & 512 \\
\hline Maize/corn & 1643 & 1403 & 1360 & 1909 & 2032 & 883 & 1637 & 1517 & 987 & 1279 & 1506 & 1849 \\
\hline Dry peas & 1170 & 966 & 1081 & 1325 & 1328 & 661 & 1145 & 1485 & 845 & 1052 & 801 & 1333 \\
\hline Soya meal & 1043 & 677 & 676 & 1012 & 1232 & 682 & 1071 & 1294 & 678 & 785 & 728 & 1074 \\
\hline Canola meal & 933 & 655 & 655 & 983 & 1201 & 655 & 1037 & 1256 & 655 & 764 & 710 & 1037 \\
\hline Mill screen & 1225 & 805 & 805 & 1208 & 1476 & 805 & 1275 & 1543 & 805 & 939 & 872 & 1275 \\
\hline Alfalfa & 733 & 596 & 658 & 708 & 830 & 401 & 771 & 841 & 607 & 724 & 613 & 648 \\
\hline Dry hay & 420 & 323 & 328 & 438 & 535 & 283 & 407 & 509 & 413 & 418 & 317 & 400 \\
\hline Silage & 420 & 317 & 322 & 438 & 535 & 283 & 407 & 509 & 401 & 397 & 317 & 400 \\
\hline Other roughages & 378 & 269 & 293 & 399 & 469 & 254 & 379 & 467 & 317 & 332 & 302 & 410 \\
\hline
\end{tabular}


by an animal, water consumption in feed production, and slaughtering age (Chapagain and Hoekstra 2003). In many developing and developed countries, livestock feed is a mixture of crops, crop residues, and industrial products (Chapagain and Hoekstra 2003). To mix the feed items, additional water is required. The VWC for feed was estimated as

$\mathrm{VWC}_{\text {feed }}=(\mathrm{CW} \times \mathrm{SA}+\mathrm{WFM})$,

where $\mathrm{CW}=$ total VWC of feed crops per animal $\left(\mathrm{m}^{3} /\right.$ year), $\mathrm{SA}=$ slaughtering age (year), and $\mathrm{WFM}=$ volume of water for mixing of food items $\left(\mathrm{m}^{3} / \mathrm{animal}\right)$. The past studies have reported that WFM was approximately $50 \%$ of the feed volume consumed by a livestock animal (Chapagain and Hoekstra 2003; Mekonnen and Hoekstra 2012). To assess CW, the weighted WFP per ton of the feed items (WFP*) and the average feed amount are necessary (AFV). Abbas (2013) reported crop water requirements (CWR) for the major crops produced in different regions of Saudi Arabia. In this study, the CROPWAT software (Version 8), recommended by Food and Agriculture Association (FAO), was used (FAO 2009). In addition, historical rainfall and temperature data for different regions were obtained from the FAO database in the CLIMWAT 2.0 software (FAO 2012). As such, climatic variability in different regions was incorporated in this calculation (Abbas 2013; Chowdhury et al. 2016). The CWR represented the water consumption in addition to the supplements from seasonal rainfall events in these regions and it was satisfied from the non-renewable groundwater sources. The calculated CWR for different crops were divided by the crop yields to obtain the WFP for the domestic feed crops, which were used in Eq. (2) to calculate the weighted WFP (WFP*).

In Tables 3, 4, 5, and 6, indicative sample calculations along with the necessary data (e.g., feed items, amounts, slaughtering ages, live weights, etc.) are presented (Chapagain and Hoekstra 2003; Khan et al. 2003; Abdallah and Faye 2013). The feed intakes vary depending on animal type, purpose, and farming practices. The feed items are divided into grain (e.g., wheat, oats, barley, corn, dry peas, soyabean, canola, mill screen, and other grains) and nongrain (e.g., pasture, dry hay, silage, other roughages, etc.) fractions. Different animals are fed with different fractions of grain and non-grain feed items. Further details on the animal specific feed intakes are shown in Table 3. In Table 3, a VWC of feed crops sample calculation is presented for each category animal per year $\left(\mathrm{CW}=\mathrm{AFV} \times \mathrm{WFP}^{*}\right)$ in Riyadh. In Table 4 , the total VWC is estimated for each category animal for up to the slaughtering age, where the $\mathrm{CW}$ from Table 3 and the VWC for drinking and service purposes for up to the slaughtering age are included. The animals produced through the grazing farming had lower weights than those of the industrial farming. These data are used to calculate the VWC for unit weight of each category animal (Table 5). In Table 6, the VWC of a hen was divided into eggs and carcass. To obtain the unit VWC for egg, data on egg and carcass produced per hen and market values were collected through field survey in the local farms. The monetary fractions for egg and carcass of hen were estimated to be 0.854 and 0.146 , respectively (Chapagain and Hoekstra 2003). These were multiplied by the VWC of hen (Table 4) to obtain the respective water share and then converted to a unit VWC (Table 6). Following a similar procedure and using the weighted WFP (WFP*) for the feed items from different regions (Table 2), the VWC was calculated for all regions.

The yearly water requirements for drinking and service purposes depend on local climatic conditions (i.e., temperature, humidity, rainfall etc.), farming practices, and the final farming product (e.g., meat or milk from cow; poultry or egg, etc.), which was estimated as

$\mathrm{VWC}_{\text {drink }}=A D D_{\mathrm{d}} \times \mathrm{SA} \times 365$

$\mathrm{VWC}_{\text {service }}=\mathrm{ADD}_{\mathrm{s}} \times \mathrm{SA} \times 365$,

where $\mathrm{ADD}_{\mathrm{d}}=$ average water consumption per animal $\left(\mathrm{m}^{3} /\right.$ day $)$ and $\mathrm{ADD}_{\mathrm{s}}=$ average water demand for service purposes (e.g., cleaning) per animal $\left(\mathrm{m}^{3} /\right.$ day)

The unit VWC was estimated per unit weight of meat (e.g., per ton). Farming practices play an important role in predicting the unit VWC. In this analysis, a 'mixed' type, meaning the mixture of 'grazing' and 'industrial' feeding, as proposed by Chapagain and Hoekstra (2003) was considered. Gerbens-Leenes et al. $(2012,2013)$ reported that the livestock produced through industrial farming were heavier than those of 'grazing' farming' and, however, previously Chapagain and Hoekstra (2003) reported the opposite. Unit VWC per animal was properly calculated (Table 5).

The total VWC for each category of livestock animal $\left(\mathrm{VWC}_{\mathrm{ti}}\right)$ was calculated as

$\mathrm{VWC}_{\mathrm{ti}}=\mathrm{VWC}_{\mathrm{ui}} \times W_{i}$,

where $\mathrm{VWC}_{\mathrm{ti}}=\mathrm{VWC}$ for i category livestock animal $\left(\mathrm{m}^{3} /\right.$ year), $\mathrm{VWC}_{\mathrm{ui}}=\mathrm{VWC}$ for one ton of animal, and $W_{i}=$ total weight of $i$ category livestock animal consumed in a year (ton/year). The value of $W_{i}$ was calculated as

$W_{i}=\mathrm{LW}_{i} \times N_{i}$,

where $L W_{i}=$ live weight on an animal (ton/animal) in Table 5 , and $N_{i}=$ no. of livestock animal slaughtered in a year (Table 1). The total virtual water content $\left(\mathrm{VWC}_{T}\right)$ was finally calculated as

$\mathrm{VWC}_{T}=\sum_{i=1}^{n} \mathrm{VWC}_{\mathrm{ti}}$. 
Table 3 Indicative calculations of VWC for feed of a farm livestock animal in Riyadh (after: Chapagain and Hoekstra 2003; Mekonnen and Hoekstra 2012; Abdallah and Faye 2013; Abbas 2013; field survey)

\begin{tabular}{|c|c|c|c|c|c|c|c|c|c|c|c|c|c|c|c|}
\hline \multirow[t]{2}{*}{ Feed crop } & \multirow[t]{2}{*}{ WFP } & \multicolumn{2}{|c|}{ Camel } & \multicolumn{2}{|l|}{ Cow } & \multicolumn{2}{|c|}{ Dairy cow } & \multicolumn{2}{|l|}{ Sheep } & \multicolumn{2}{|l|}{ Goat } & \multicolumn{2}{|l|}{ Poultry } & \multicolumn{2}{|c|}{ Laying hen } \\
\hline & & $\mathrm{AFV}$ & $\mathrm{CW}$ & $\mathrm{AFV}$ & $\mathrm{CW}$ & $\mathrm{AFV}$ & $\mathrm{CW}$ & $\mathrm{AFV}$ & $\mathrm{CW}$ & AFV & $\mathrm{CW}$ & $\mathrm{AFV}$ & $\mathrm{CW}$ & $\mathrm{AFV}$ & $\mathrm{CW}$ \\
\hline Wheat & 1123 & 0.53 & 595 & 0.0069 & 8 & 0.055 & 62 & 0.000625 & 1 & & & 0.0054 & 6.1 & 0.0054 & 6.0 \\
\hline Oats & 2081 & 0.12 & 250 & 0.0889 & 185 & 0.01 & 21 & 0.001875 & 4 & 0.0015 & 3 & & & & \\
\hline Barley & 669 & 0.237 & 159 & 0.1392 & 93 & 0.462 & 309 & 0.011125 & 7 & 0.0049 & 3 & & & & \\
\hline Other grains & 533 & & & 0.0042 & 2 & 0.0315 & 17 & 0.000375 & & 0.0004 & 0 & & & & \\
\hline Maize/corn & 1643 & & & 0.0363 & 60 & 0.8495 & 1396 & 0.001625 & 3 & 0.00225 & 4 & 0.0051 & 8.4 & 0.0051 & 8.2 \\
\hline Dry peas & 1170 & 1.2 & 1405 & 0.0048 & 6 & 0.0018 & 2 & 0.0015 & 2 & & 0 & & & & \\
\hline Soyabean meal & 1043 & & & 0.009 & 9 & 0.1555 & 162 & 0.00075 & 1 & 0.00075 & 1 & 0.0017 & 1.8 & 0.0017 & 2.2 \\
\hline Canola meal & 933 & & & 0.0077 & 7 & 0.06 & 56 & 0.000375 & 0 & 0.0004 & 0 & 0.001 & 0.9 & 0.001 & 1.1 \\
\hline Mill screen & 1225 & & & 0.0195 & 24 & 0.13 & 159 & 0.000625 & 1 & & 0 & 0.0009 & 1.1 & 0.0009 & 1.2 \\
\hline Total grain & & 2.087 & & 0.3165 & & 1.765 & & 0.018875 & & 0.0102 & 0 & 0.0141 & & 0.0141 & \\
\hline Non grain portion & 413 & & & 0.007 & 3 & 0.096 & 40 & 0.000375 & & 0.0004 & 0 & 0.0033 & 1.4 & 0.0033 & 1.2 \\
\hline Pasture & 733 & 1.26 & 923 & 1.123 & 823 & 0.41 & 300 & 0.11075 & 81 & 0.065 & 48 & & & & \\
\hline Dry hay & 420 & & & 0.8565 & 360 & 1.285 & 540 & 0.14175 & 60 & 0.03815 & 16 & & & & \\
\hline Silage & 420 & & & 0.4195 & 176 & 3.715 & 1560 & 0.0255 & 11 & 0.00065 & 0 & & & & \\
\hline Other roughages & 378 & & & 0.196 & 74 & & & 0.00225 & & & & & & & \\
\hline Total feed volume & & 3.347 & & 2.303 & & 5.41 & & 0.2995 & & 0.1144 & & 0.0174 & & 0.0174 & \\
\hline Total water for fee & per ye & & 3331 & & 1829 & & 4623 & & 170 & & 76 & & 20 & & 20 \\
\hline
\end{tabular}

WFP weighted average water footprint for feed items $\left(\mathrm{m}^{3} /\right.$ ton), $A F V$ average feed amount (ton/year), $C W$ VWC of feed $\mathrm{crops}$ per animal $\left(\mathrm{m}^{3} /\right.$ year)

Table 4 Calculation of VWC for a livestock animal at the age of slaughtering

\begin{tabular}{|c|c|c|c|c|c|c|c|c|c|c|}
\hline \multirow[t]{3}{*}{ Animal } & \multirow[t]{3}{*}{ SA } & \multicolumn{2}{|c|}{$\mathrm{VWC}_{\text {drink }}$} & \multicolumn{2}{|c|}{$\mathrm{VWC}_{\text {service }}$} & \multicolumn{4}{|l|}{$\mathrm{VWC}_{\text {feed }}$} & \multirow[t]{3}{*}{$\mathrm{VWC}_{i}$} \\
\hline & & \multirow[t]{2}{*}{ ADD } & \multirow[t]{2}{*}{ TDD } & \multirow[t]{2}{*}{ ADD } & \multirow[t]{2}{*}{ TSD } & \multicolumn{2}{|l|}{$\mathrm{VWC}_{\mathrm{FI}}$} & \multicolumn{2}{|l|}{$\mathrm{VWC}_{\mathrm{M}}$} & \\
\hline & & & & & & $\mathrm{VWC}_{\mathrm{FY}}$ & $\mathrm{VWC}_{\mathrm{FT}}$ & $\mathrm{VWC}_{\mathrm{MY}}$ & $\mathrm{VWC}_{\mathrm{MT}}$ & \\
\hline Camel & 4 & 30 & 43.80 & 6.5 & 9.49 & 3331 & 13324.4 & 1.67 & 6.69 & 13384.3 \\
\hline Cow & 3 & 21.5 & 23.54 & 6.5 & 7.12 & 1829 & 5488.3 & 1.15 & 3.46 & 5522.5 \\
\hline Dairy cow ${ }^{a}$ & 8.83 & 33.9 & 109.3 & 4.3 & 13.9 & 4623 & 40823.4 & 2.71 & 23.9 & 40970.4 \\
\hline Sheep & 1.5 & 3.98 & 2.18 & 3.5 & 1.92 & 170 & 254.6 & 0.15 & 0.23 & 258.9 \\
\hline Goat & 2 & 2.09 & 1.53 & 2.5 & 1.83 & 76 & 151.1 & 0.057 & 0.11 & 154.6 \\
\hline Poultry & 0.20 & 0.28 & 0.02 & 0.14 & 0.01 & 20 & 3.92 & 0.009 & 0.002 & 3.96 \\
\hline Hen & 1.44 & 0.24 & 0.13 & 0.12 & 0.06 & 20 & 28.2 & 0.009 & 0.013 & 28.45 \\
\hline
\end{tabular}

${ }^{a}$ Dairy cow total life time $=10$ years $[0-1$ year $=$ calves; $1-3$ years $=$ heifers; $3-10$ years $=$ dairy, equivalent to 8.83 years of dairy period $S A$ average slaughtering age (year), $A D D$ average daily demand (1/day), TDD total drinking demand: $\left(\mathrm{m}^{3} /\right.$ animal), TSD total service demand ( $\mathrm{m}^{3} /$ animal), $V W C_{\text {drink }}$ VWC for drinking, $V W C_{\text {service }}$ VWC for servicing, $V W C_{\text {feed }}$ VWC for feed, $V W C_{F I}$ VWC for feed intake, $V W C_{F Y}$ VWC for feed intake in 1 year $\left(\mathrm{m}^{3} /\right.$ year), $V W C_{F T}$ VWC for total feed intake $\left(\mathrm{m}^{3} /\right.$ animal), $V W C_{M}$ VWC for feed mixing, $V W C_{M Y}$ VWC for feed mixing in 1 year $\left(\mathrm{m}^{3} /\right.$ year), $V W C_{M T} \mathrm{VWC}$ for total feed mixing $\left(\mathrm{m}^{3} / \mathrm{animal}\right), V W C_{i}$ overall $\mathrm{VWC}$ for $i$ category animal $\left(\mathrm{m}^{3} / \mathrm{animal}\right)$ 
Table 5 Calculation of VWC for unit weight of a livestock animal meat at slaughtering age

\begin{tabular}{|c|c|c|c|c|}
\hline \multirow[t]{2}{*}{ Type of animal/bird } & \multicolumn{3}{|l|}{$\mathrm{LW}_{i}$} & \multirow[t]{2}{*}{$\mathrm{VWC}_{\mathrm{ui}}$} \\
\hline & Grazing & Industrial & Mixed $^{+}$ & \\
\hline Camel & 0.63 & 0.726 & 0.678 & 19,741 \\
\hline Cow & 0.4 & 0.545 & 0.4725 & 11,688 \\
\hline Dairy cow & 0.27 & 0.45 & 0.36 & 113,807 \\
\hline Sheep & 0.04 & 0.053 & 0.0465 & 5568 \\
\hline Goats & 0.035 & 0.04 & 0.0375 & 4122 \\
\hline Poultry & 0.0018 & 0.0022 & 0.002 & 1978 \\
\hline Hen & 0.0015 & 0.002 & 0.00175 & 16,256 \\
\hline
\end{tabular}

$L W_{i}$ living weight of $i$ category animal (ton/animal), $V W C_{u i}$ unit VWC of $i$ category animal $\left(\mathrm{m}^{3} / \mathrm{ton}\right)$

Table 6 Dividing the VWC between the carcass and eggs of a hen

\begin{tabular}{llllllll}
\hline Product & $\mathrm{W}_{\mathrm{E}}$ & $\mathrm{M}_{\mathrm{P}}$ & $\mathrm{M}_{\mathrm{V}}$ & $\mathrm{T}_{\mathrm{P}}$ & $\mathrm{V}_{\mathrm{F}}$ & $\mathrm{W}_{\mathrm{S}}$ & $\mathrm{VWC}_{\mathrm{ui}}^{\mathrm{a}}$ \\
\hline Egg & 0.00882 & 13889 & 122.5 & 143.5 & 0.854 & $24.28=(\approx 28.45 \times 0.854)$ \\
Carcass & 0.00175 & 12,000 & 21 & & 0.146 & 4.16 & 2753 \\
\hline
\end{tabular}

$W_{E}$ weight of egg (ton/hen), $M_{P}$ market price (SR/ton), $M_{V}$ monetary value of product (SR/hen), $T_{P}$ total price (SR/hen), $V_{F}$ value fraction, $W_{S}$ water share $\left(\mathrm{m}^{3} /\right.$ product/hen), Egg each hen produces $210 \mathrm{of}$ eggs in their life period; weight of an egg $=42 \mathrm{~g} ; \mathrm{price}$ of an egg $=\mathrm{SR} 0.58 ; 1$ ton $=23,810$ eggs, Carcass price of $1 \mathrm{~kg}$ of hen $=$ SR. 12

${ }^{a}$ Data obtained by adjusting the $\mathrm{VWC}_{i}$ from Table 4 by the weights of mixed farming

\section{Result}

\section{Production of livestock}

From 2006 to 2010, production of camel, sheep, goat, and poultry was decreased by $24.3,35.5,54$, and $17.4 \%$, respectively, while production of cow, dairy cow, and eggs was increased by $6.5,48.5$, and $26.1 \%$, respectively. The data demonstrate decreasing trends for camel in most regions (4.8-66.7\%) except Madinah, Jazan, and Al-Baha, where camel production was increased by $33.3-100 \%$ (Table 1). Production of cow was increased in Riyadh, Qaseem, Hail, and Al-Baha by 6.7-33.3\%. Production of dairy cow was also increased in Riyadh and Eastern region by 41.8 and $81.8 \%$, respectively. In this period, sheep production was decreased in all regions except the Northern region, while goat production was decreased in all regions. Production of poultry was increased in Qaseem, Aseer, Tabouk, Hail, and Najran regions, while egg production was increased in all regions except Najran and AlBaha (Table 1).

The percentile distributions of the livestock animals are shown in Fig. 1. Most of the camel was produced in Riyadh (42.5-42.9\%) followed by Qaseem (9.4-12.1\%) and Eastern region (8-12.1\%). The cow was produced mostly in Riyadh (51.5-58.5\%) and Eastern region
(24.2-28.2\%). The dairy cow was also highest in Riyadh (65.9-69.0\%) and Eastern region (25.5-31.3\%). In 2006 and 2010, production of camel, cow, and dairy cow did not show significant shift in terms of the regions. The production of camel and cow was likely to have the major shares of VWC in the livestock farms, indicating that the regions with higher numbers of these animals might have sustained pressure on the groundwater resources.

\section{Livestock feed and unit virtual water content}

The regional-weighted WFP of the main feed items is shown in Table 2. Significant fractions of the grain items were imported from the other countries. For an example, Saudi Arabia imported 1.92 million metric tons (MMT) of corn in 2010-2011, which was increased to 2.9 MMT during 2014-2015, while the country consumed 3.1 MMT (CDSI (Central Department of Statistics and Information) 2012; USDA 2016). Most of the imported corn was used for animal feed processing (USDA 2016). Corn is a very important feed grain for the poultry farms, dairy farms, livestock meat products, and commercial feed items (USDA 2016). The country imported 2.36 MMT of wheat during 2010-2011, which was increased to 3.49 MMT during 2014-2015, while the national consumption was 3.35 MMT. Wheat is an important grain for producing 
Fig. 1 Percentile distributions of livestock in different regions of Saudi Arabia. $C$ camel, $B$ cow (only for meat production), $M B$ dairy cow, $S$ sheep, $G$ goat, $P$ poultry. Notations 1 and 2 represent year 2006 and 2010

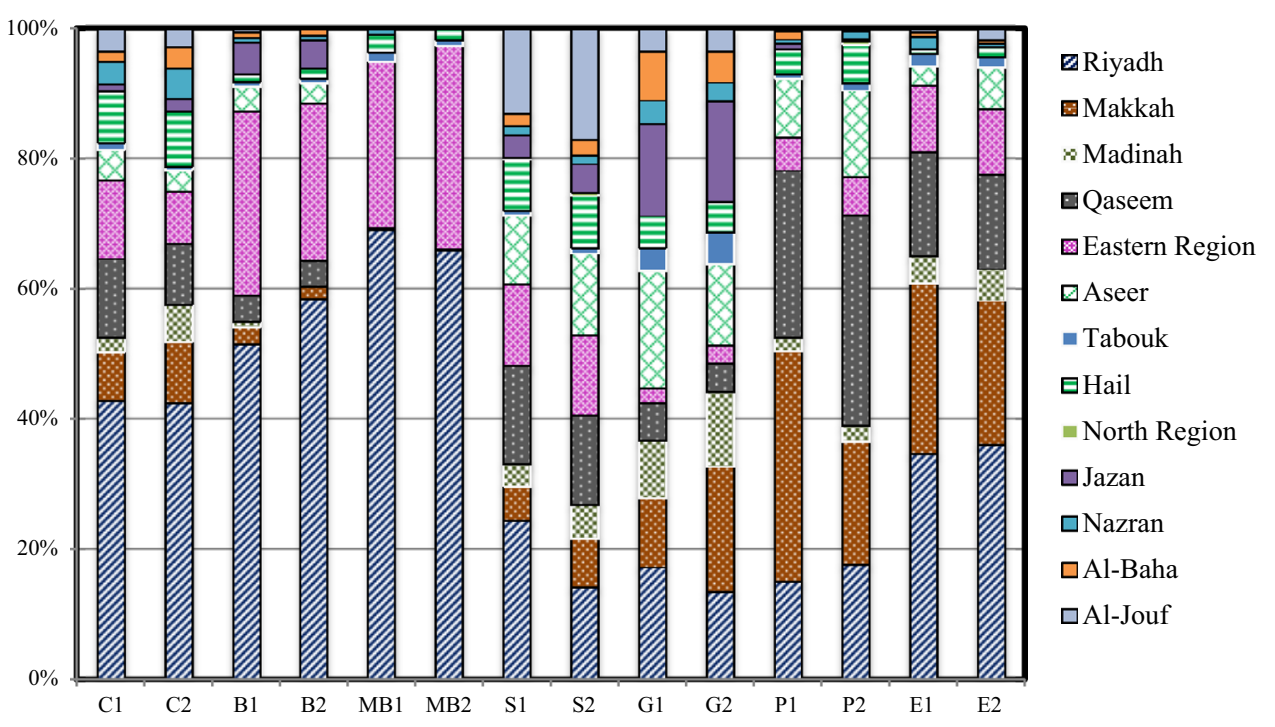

most of the livestock, poultry, and egg, while domestic wheat production was ended in 2015-2016, indicating possible increase in import in the future (CDSI 2012; USDA 2016). Domestic production of barley was terminated in 2003. In 2010-2011, 8.32 MMT of barley was imported, which was increased to 8.5 MMT in 2015-2016. About $80 \%$ of barley was used for feeding sheep, camels, and goats (USDA 2016). The country also imported 1.24 MMT of other grain crops (CDSI 2012). In 2010-2011, 46050 MT of dried chick peas were imported (CDSI 2012). In addition, production of domestic fodder crops is likely to be phased out by 2019, while fodder crops are an important feed item for producing livestock animals (USDA 2016). Further details on the import of different feed items and domestic productions can be found in the literature (CDSI 2012; SSYB 2011).

The feed compositions for camel, cow, dairy cow, sheep, goat, poultry, and hen are shown in Table 3. The corresponding feed amounts are 3.347, 2.303, 5.41, 0.2995, $0.1144, \quad 0.0174$, and 0.0174 ton/year, respectively (Table 3). On average, feed of one camel is equivalent to the feed of 1.5 cows (Table 5). The feed of a dairy cow is 2.4 times the feed of a cow. Among the feed of camel, cow, dairy cow, sheep, goat, poultry, and hen, approximately $62.4,13.7,32.6,6.3,8.9,81$, and $81 \%$ are grain or grain products, respectively. The unit VWC for these animals were predicted to be $19,741,11,688,113,807,5568,4122$, 1978 , and $16,256 \mathrm{~m}^{3} /$ ton, respectively. Worth to notice that a unit VWC for dairy cow included the VWC of producing milk for 7 years (3-10 years of life), while approximately $96 \%$ of the unit VWC was associated with milk production (Chapagain and Hoekstra 2003). The unit VWC for egg was calculated as $2753 \mathrm{~m}^{3} /$ ton. The calculation of a unit VWC for egg was performed using the average of 210 eggs per hen during its lifetime, and the weights of 0.042 and
$1.75 \mathrm{~kg}$ per egg and hen, respectively (Abdallah and Faye 2013; Chapagain and Hoekstra 2003). On average, approximately $8.82 \mathrm{~kg}(210 \times 0.042)$ of eggs are obtained from a hen. The total value of eggs and carcass of a hen was approximately SR 143.5 (US\$ 38.3), in which $85.4 \%$ was attributed to eggs (Table 6). The unit VWC was highest for camel followed by cow, whereas poultry production needed the lowest VWC (Tables 4, 5, 6). Variability in the unit VWC for different livestock animals indicates that there might be a scope to allocate livestock in different regions for water saving purposes.

\section{Total virtual water content}

The total VWC were in the range of $8.9-10.6$ billion $\mathrm{m}^{3} /$ year for the period of 2006-2010 (Table 7). The camel and cow had the highest fractions attributing $31.5-36.6 \%$ and $20.5-25.7 \%$ of total VWC, respectively. In 2010, the countrywide VWC for camel, cow, dairy cow, sheep, goat, poultry, and eggs were $2799,2274,996,1341,135,1042$, and 297 million $\mathrm{m}^{3}$, respectively. These data showed an increase of VWC for cow, dairy cow, and egg in comparison with the VWC in 2006 (Table 7). The regional distribution of VWC is shown in Fig. 2. The VWC were highest in Riyadh followed by Eastern region, Qaseem, Hail, and Makkah with ranges of 3587-4112, 1684-2044, 1007-1331, 644-810, and 504-715 million $\mathrm{m}^{3} / \mathrm{year}$, respectively. The lowest VWC was calculated for the Northern region. Three regions (Riyadh, Eastern region, and Qaseem) contributed 69.5-72.4\% of the total VWC in the country (Table 7).

In 2010, VWC for camel was highest in Riyadh (1204 million $\left.\mathrm{m}^{3}\right)$. In this year, cow had the highest VWC in Riyadh (1269 million $\mathrm{m}^{3}$ ) followed by Eastern region (679 million $\mathrm{m}^{3}$ ). The dairy cow was mainly produced in Riyadh 
Table 7 Trend of virtual water content (million $\mathrm{m}^{3}$ ) for farm livestock production in Saudi Arabia

\begin{tabular}{lrrrrrrrrrrrrrrrr}
\hline & Camel & & Cow & \multicolumn{4}{c}{ Dairy cow } & Sheep & & Goat & & Poultry & Egg & Major animal \\
\hline Region & 2006 & 2010 & 2006 & 2010 & 2006 & 2010 & 2006 & 2010 & 2006 & 2010 & 2006 & 2010 & 2006 & 2010 \\
Riyadh & 1605 & 1204 & 1048 & 1269 & 421 & 597 & 512 & 191 & 60 & 21 & 200 & 192 & 87 & 113 & Cow + camel \\
Makkah & 198 & 189 & 39 & 27 & 0 & 0 & 77 & 71 & 26 & 22 & 329 & 146 & 46 & 49 & Camel + poultry \\
Madinah & 56 & 113 & 11 & 0 & 0 & 0 & 51 & 49 & 22 & 13 & 20 & 19 & 7 & 11 & Camel + sheep \\
Qaseem & 482 & 284 & 87 & 94 & 4 & 3 & 337 & 197 & 22 & 7 & 358 & 374 & 42 & 49 & Poultry + camel \\
Eastern region & 589 & 295 & 743 & 679 & 201 & 366 & 336 & 215 & 10 & 6 & 87 & 84 & 33 & 41 & Cow + camel \\
Aseer & 123 & 66 & 55 & 47 & 0 & 0 & 157 & 121 & 44 & 14 & 85 & 101 & 5 & 14 & Sheep + poultry \\
Tabouk & 45 & 15 & 18 & 18 & 10 & 9 & 18 & 12 & 13 & 9 & 10 & 13 & 5 & 6 & Cow + camel \\
Hail & 398 & 325 & 30 & 45 & 23 & 22 & 224 & 147 & 23 & 10 & 67 & 89 & 2 & 6 & Camel \\
Northern region & & & & & & & 4 & 7 & & & 0 & 6 & & Sheep + poultry \\
Jazan & 28 & 38 & 70 & 66 & 0 & 0 & 51 & 42 & 35 & 17 & 7 & 3 & & Cow + sheep \\
Nazran & 110 & 110 & 13 & 13 & 4 & 0 & 3 & 5 & 10 & 4 & 7 & 10 & 4 & 1 & Camel \\
Al-Baha & 41 & 72 & 12 & 17 & 0 & 0 & 30 & 26 & 20 & 6 & 13 & 1 & 1 & 1 & Camel \\
Al-Jouf & 149 & 89 & 12 & 0 & 0 & 0 & 306 & 257 & 13 & 7 & 6 & 5 & 1 & 7 & Sheep \\
Total & 3823 & 2799 & 2139 & 2274 & 662 & 996 & 2104 & 1341 & 298 & 135 & 1189 & 1042 & 234 & 297
\end{tabular}

Empty cell no data due to very low numbers

Fig. 2 Regional VWC for livestock and eggs (million $\mathrm{m}^{3}$ ) produced in 2006-2010 period

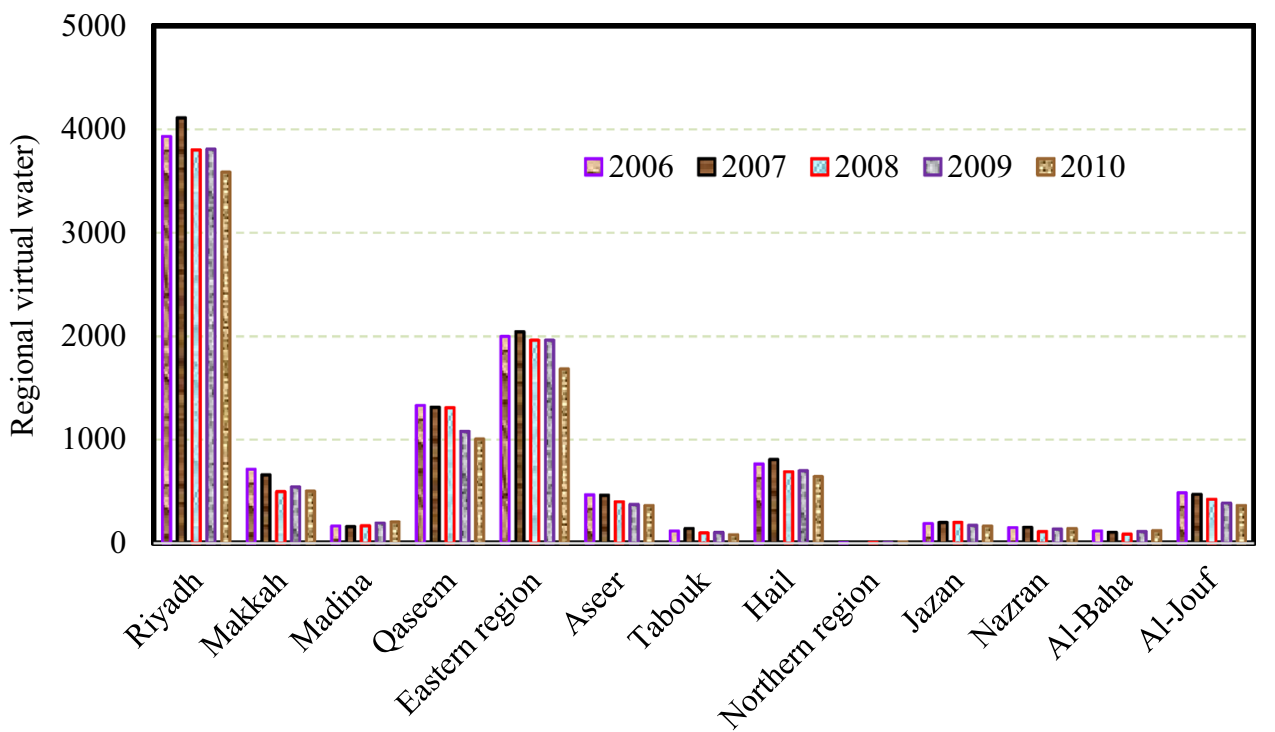

and Eastern region with VWC of 597 and 366 million $\mathrm{m}^{3}$, respectively. VWC for sheep and goat were highest in AlJouf and Makkah, respectively. VWC for poultry were highest in Qaseem followed by Riyadh, Makkah, and Aseer (Table 7), while the VWC of egg were highest in Riyadh followed by Makkah, Qaseem, and Eastern region. The VWC distribution is explained in Fig. 3. In 2010, total VWC in Riyadh was 3587 million $\mathrm{m}^{3}$, in which camel, cow, and dairy cow had 33.6, 35.4, and $16.6 \%$, respectively. In this year, the second largest VWC was in Eastern region (1684.1 million $\mathrm{m}^{3}$ ), where camel, cow, and dairy cow had the VWC of $18.1,40.3$, and $21.8 \%$, respectively.
The third largest VWC was for Qaseem region (1007.1 million $\mathrm{m}^{3}$ ), where poultry and camel were the main livestock attributing 37.2 and $28.2 \%$ of VWC, respectively (Table 7; Fig. 3). Further details on VWC can be obtained from Figs. 2 and 3 and Table 7.

The geographical distribution of VWC in 2006 and 2010 is shown in Fig. 4. In these years, the largest VWC for livestock farms were for Riyadh, Eastern region, Qaseem, Hail, and Makkah (>500 million $\mathrm{m}^{3} /$ year). These five regions showed the decreasing trends for VWC during 2006-2010. The distributions of VWC were not consistent to the population distributions. The populations in Riyadh, 
Fig. 3 Percentile distributions of product specific regional VWC in 2006 and 2010. $C$ camel, $B$ cow (only for meat production), $M B$ dairy cow, $S$ sheep, $G$ goat, $P$ poultry, $E$ egg; subscripts 1 and 2 represents 2006 and 2010

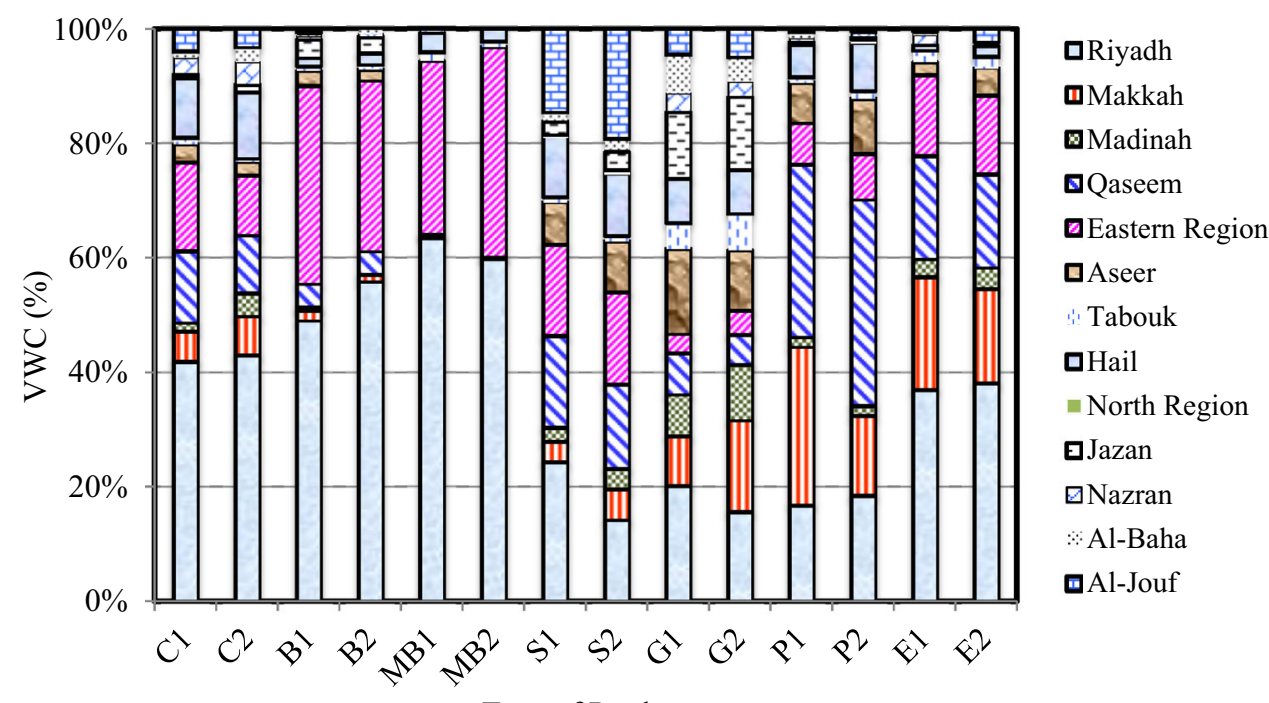

Type of Product
Fig. 4 Regional distribution of VWC for livestock farms in

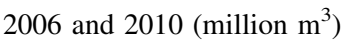
(first value: VWC in 2006; second value: VWC in 2010)

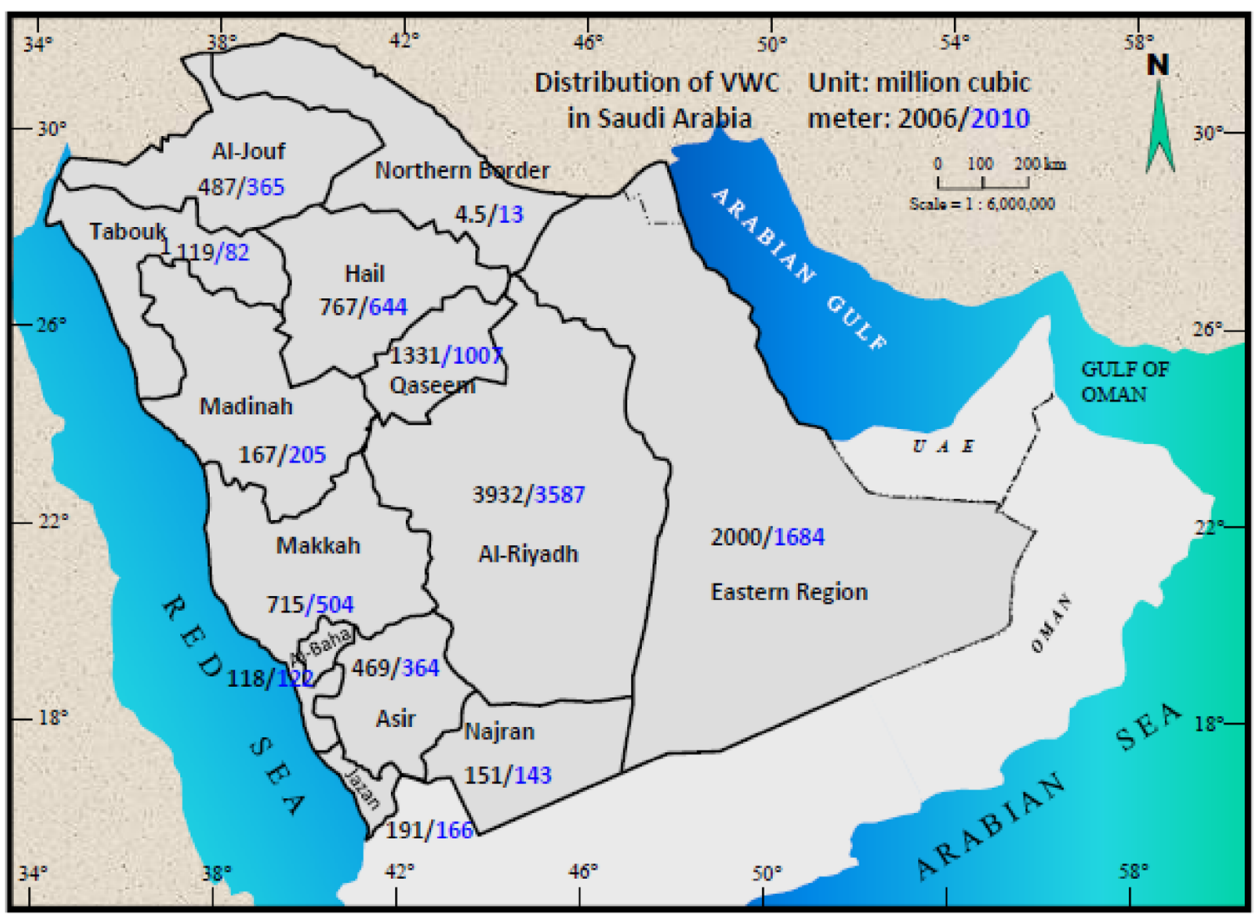

Eastern region, Qaseem, Hail, and Makkah were 6.8, 4.1, 1.2, 0.6, and 6.9 million, respectively (SSYB 2011). Makkah had more populations than Riyadh, while the VWC in Makkah were less than $20 \%$ of Riyadh (Fig. 4). The VWC in Eastern region, Qaseem, and Hail were higher (Fig. 4). It is to be noted that the higher VWC for livestock farms were consistent to the regions with higher agricultural crop productions (SSYB 2011; Abbas 2013). The higher levels of agricultural activities and livestock farms might have higher stress on the non-renewable groundwater sources, which deserves better understanding.

\section{Trend of virtual water content}

The highest and lowest VWC were estimated for 2007 and 2010 with the values of 10.6 and 8.9 billion $\mathrm{m}^{3}$, respectively. The VWC for camel, sheep, goat, and poultry were decreased by $26.8,36.3,54.5$, and $12.4 \%$, respectively, from 2006 to 2010, while the VWC for cow, dairy cow, and egg were increased by $6.3,50.4$, and $26.7 \%$, respectively (Fig. 5). In these years, VWC for camel were highest (2799-3823 million $\mathrm{m}^{3} /$ year), while a decreasing trend from 2006 to 2010 was observed (Fig. 5). In 2006, VWC for cow was 2139 million $\mathrm{m}^{3}$, which was increased to 2464 


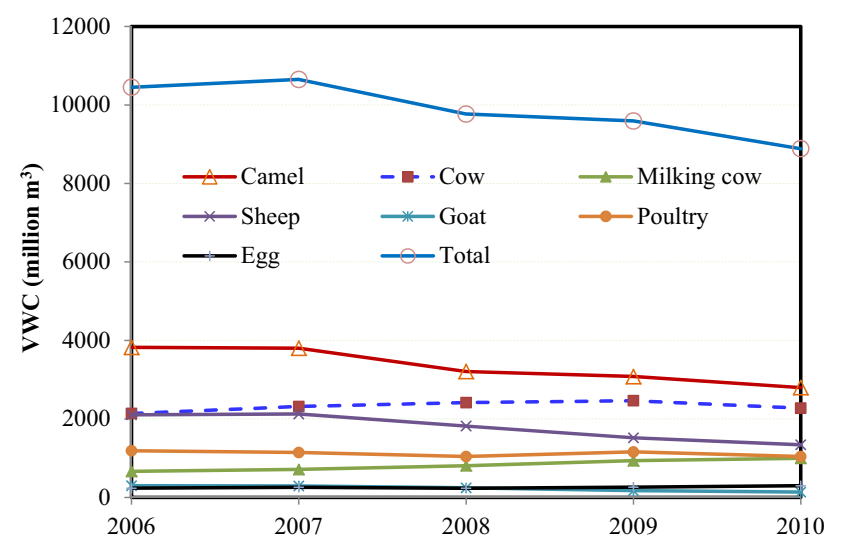

Fig. 5 Trends of VWC for livestock and egg produced in Saudi Arabia (million $\mathrm{m}^{3}$ )

million $\mathrm{m}^{3}$ in 2009 and then decreased to 2274 million $\mathrm{m}^{3}$ in 2010. The VWC for dairy cow was increased from 662 to 996 million $\mathrm{m}^{3}$ during 2006-2010. VWC for sheep was decreased from 2104 to 1341 million $\mathrm{m}^{3}$ in this period. For egg, VWC showed variable trend (Fig. 5) with the values of $234,258,233,261$, and 297 million $\mathrm{m}^{3}$ in 2006, 2007, 2008, 2009, and 2010, respectively. VWC for goat was decreased from 298 million $\mathrm{m}^{3}$ in 2006 to 135 million $\mathrm{m}^{3}$ in 2010. Further details on VWC for each category of animal are shown in Table 7.

\section{Comparative analysis}

The unit VWC of camel was 1.7 and 3.5 times the unit VWC for cow and sheep, respectively (Table 8). One kg of camel and cow meat required 19.7 and $14.6 \mathrm{~kg}$ of feed supply, respectively. Production of $1 \mathrm{~kg}$ of sheep, goat, and poultry required $9.66,6.1$, and $1.65 \mathrm{~kg}$ of feed, respectively (Table 8). The dairy cow had the highest unit VWC, in which about $96 \%$ was due to milk production for 7 years (Chapagain and Hoekstra 2003). The VWC for some livestock animals in this analysis were different from the ones reported in the literature (Chapagain and Hoekstra
2003; Mekonnen and Hoekstra 2010). The variability in VWC might be attributed to several factors, including the way VWC, is estimated using the gross national income instead of field data, local feeding practices, and impact of local climatic conditions.

The decrease in production of some livestock animals was responsible for the reduced VWC in 2010. Camel production was decreased by $25 \%$ since 2006 and the corresponding VWC was reduced by $26.8 \%$. Production of cow was increased by $6.0 \%$ and the related VWC was increased by $6.3 \%$. Production of dairy cow and VWC was increased by 48.5 and $50.4 \%$, respectively. During the same period, VWC for sheep, goat, poultry, and egg were changed by $-36.3,-54.6,-12.4$, and $+26.7 \%$, respectively, which were reflecting the changes in their productions (Table 1). The changes in livestock productions showed minimal variation with respect to the changes in VWC, indicating that significant technological improvements might have not been taken place during this period. However, it is to be noted that the temporal changes in farming practices were not considered in this study. The five regions (Riyadh, Eastern region, Qaseem, Hail, and Makkah) consumed 83.6-84.6\% of total VWC during 2006-2010. In Riyadh, Eastern region, Qaseem, and Makkah, VWC were decreased by 8.8, 15.7, 24.3, and $29.5 \%$, respectively, during this period. In Madinah and AlBaha, VWC were increased from 2006 to 2010. In Madinah, camel and egg productions were increased, while in Al-Baha, camel, and cow productions were increased. The shift of livestock productions in different regions can have implications on the policy, water resources, and feed supplies.

\section{Policy implications}

The findings indicated that there were minimal technological and/or managerial developments for water conservation in livestock farms. Saudi Arabia should invest in

Table 8 Comparison of different livestocks in context to unit virtual water content (Riyadh region)

\begin{tabular}{lllllllll}
\hline & Camel & Cow & Dairy cow ${ }^{\mathrm{a}}$ & Sheep & Goats & Egg & Poultry & Comment \\
\hline VWC $\left(\mathrm{m}^{3} /\right.$ ton $)$ & $\mathrm{NR}$ & 11,359 & 148,223 & 5904 & 4179 & NR & 4146 & Past study \\
VWC $\left(\mathrm{m}^{3} /\right.$ ton) & 19,741 & 11,688 & 113,807 & 5568 & 4122 & 2753 & 1978 & Current study \\
Slaughtering age (year) & 4 & 3 & 10 & 1.5 & 2 & 1.44 & 0.20 & Current study \\
Weight (ton/animal) & 0.678 & 0.473 & 0.36 & 0.0465 & 0.038 & 0.00882 & 0.002 & Current study \\
Feed consumption: ton/year/animal & 3.347 & 2.303 & 5.41 & 0.2995 & 0.114 & 0.0174 & 0.0174 & Current study \\
Feed consumed in lifetime (ton) & 13.388 & 6.909 & 47.77 & 0.4493 & 0.229 & 0.0251 & 0.00331 & Current study \\
Feed consumed (kg feed/kg product) & 19.75 & 14.62 & 132.7 & 9.66 & 6.101 & 2.84 & 1.65 & Current study \\
\hline
\end{tabular}

$N R$ not reported

${ }^{\text {a }}$ The main product is milk $(\approx 96 \%)$ during the lifetime (e.g., 3-10 years) and feed consumption for 10 years 
technological and managerial water saving programs to reduce water consumption in these farms. Another possible move may be the shift of diet from high the VWC meat (e.g., camel, cow) to low VWC meat (e.g., poultry). However, such a shift needs to be assessed from social, cultural, and nutritional aspects. In particular, the needs of protein and energy should be compared. Future study is warranted on nutritional equivalency for substituting the meat intake habit.

In this study, VWC for few livestock animals was not calculated due to the lack of data. VWC for secondary products, such as cheese, butter, leather, etc. was not estimated in this analysis. Upon availability of data, future study may further improve these estimates. Effects of temperature variability in different regions were not explicitly evaluated. In addition, the previous studies have indicated that climate change might implicitly affect the VWC via the impacts on agricultural water demand (Papadopoulou et al. 2016). Future study is recommended to fulfill these limitations towards a better understanding of the overall and regional VWC in the livestock farms. The VWC trade balance in Saudi Arabia needs further investigation to identify the actual water consumption of livestock production in relation with VWC import/export. The authors are currently conducting a study to estimate the green, blue, and grey components of water footprint in livestock industry in Saudi Arabia. The economic and financial feasibility of water consumption in livestock production and the opportunity cost of this consumption need to be investigated. The findings documented in this study will form the foundation for an economic and financial feasibility study. Despite the limitations as noted above, the findings of this analysis shed light on water consumption in the livestock farming and egg production in Saudi Arabia.

\section{Conclusions}

In this study, VWC for livestock farms in the 13 regions of Saudi Arabia from 2006 to 2010 were predicted by comparing and analyzing the regional variability of livestock production. This study estimated the VWC for camel production through farming, which was not reported earlier. Camel production was associated with a large fraction of VWC. The analysis showed that the overall VWC for livestock production were 10.6 and 8.9 billion $\mathrm{m}^{3} /$ year in 2006 and 2010, respectively. Despite the decrease in overall VWC, VWC for cow, dairy cow, and egg were increased in the same period, which can be related to the high financial return of cow, dairy cow, and egg. This study shows that a shift in diet from the high VWC meat to low VWC meat may reduce the overall VWC for livestock production. However, protein and energy equivalency need to be investigated for any shift of diet. Our findings highlight the value of VWC in understanding water consumption pattern in the livestock farming and identifying methods to increase its efficiency to save water through appropriate allocation of livestock farms in different regions and attribute control over the production of the high VWC animals as an integral part of a comprehensive agricultural water management strategy. In conclusion, future work should be paid to provide a compressive regional and national overview of VWC for livestock farming in Saudi Arabia to obtain the development of a knowledge-based agricultural water management strategy in the Kingdom towards the optimal management of water resources.

Acknowledgements The authors would like to acknowledge the support provided by the Deanship of Scientific Research (DSR) at King Fahd University of Petroleum \& Minerals (KFUPM) for funding this work through project No. RG 1410-1 \& 2 .

Open Access This article is distributed under the terms of the Creative Commons Attribution 4.0 International License (http:// creativecommons.org/licenses/by/4.0/), which permits unrestricted use, distribution, and reproduction in any medium, provided you give appropriate credit to the original author(s) and the source, provide a link to the Creative Commons license, and indicate if changes were made.

\section{References}

Abbas (2013) Implications of climate change on crop water requirements in Saudi Arabia. Masters thesis, King Fahd University of Petroleum and Minerals, Dhahran 31261, Saudi Arabia

Abdallah HR, Faye B (2013) Typology of camel farming system in Saudi Arabia. Emir J Food Agric 25:250-260

Alexandratos N, Bruinsma J (2012) World food and agriculture to 2030/50: The 2012 revision. FAO, Rome, p 32

Allan JA (1993) Fortunately there are substitutes for water otherwise our hydro-political futures would be impossible. Priorities for water resources allocation and management. ODA, London, pp 13-26

Allan JA (1994) Overall perspectives on countries and regions. In: Rogers P, Lydon P (eds) Water in the Arab World: perspectives and prognoses. Harvard University Press, Cambridge, pp 65-100

Allan T (1997) Virtual water': a long term solution for water short Middle Eastern economies? In: paper presented at the 1997 British Association Festival of Science, Roger Stevens Lecture, University of Leeds, Water and Development SessionTUE.51.14.45, 9 September 1997

Al-Shayaa MA, Gaig MB, Strquadine GS (2012) Agricultural extension in the Kingdom of Saudi Arabia: difficult present and demanding future. J Anim Plant Sci 22(1):239-246

Al-Zahrani KH, Baig MB (2011) Water in the Kingdom of Saudi Arabia: sustainable management options. J Anim Plant Sci 21(3):601-613

Al-Zahrani M, Chowdhury S, Abo-Monasar A (2015) Augmentation of surface water sources from spatially distributed rainfall in Saudi Arabia. J Water Reuse Desalination 5(3):391-406 
CDSI (Central Department of Statistics and Information) (2012). Import Statistics of Saudi Arabia in 2012

Chapagain AK, Hoekstra AY (2003) Virtual water flows between nations in relation to trade in cattle livestock and livestock products. Value of Water Research Report Series No. 13. UNESCO-IHE, Delft, The Netherlands

Charchousi D, Tsoukala VK, Papadopoulou MP (2015) How evapotranspiration process may affect the estimation of water footprint indicator in agriculture? Desalination Water Treat 53(12):3234-3243

Chowdhury S, Al-Zahrani M (2013) Reuse of treated wastewater in Saudi Arabia: an assessment framework. J Water Reuse Desalination 03(3):297-314

Chowdhury S, Al-Zahrani M, Abbas A (2016) Implications of climate change on crop water requirements in arid region: an example of Al-Jouf, Saudi Arabia. J King Saud Univ Eng Sci 28:21-31

City population (2016) Saudi Arabia. https://www.citypopulation.de/ SaudiArabia.html. Accessed 26 April 2017

de Boer IJM, Hoving IE, Vellinga TV, Ven GWJ, Leffelaar PA, Gerber PJ (2013) Assessing environmental impact associated with fresh water consumption along the life cycle of animal products: the case of Dutch milk production in Noord-Brabant. Int J Life Cycle Assess 18:193-203

FAO (Food and Agriculture Organization) (2009) CROPWAT software, Food and Agriculture Organization, Land and Water Division. http://www.fao.org/nr/water/infores_databases_ cropwat.html

FAO (Food and Agriculture Organization) (2012) CLIMWAT: A climatic database for irrigation planning and management, FAO. http://www.fao.org/nr/water/infores_databases.html. Accessed 10 Sept 2012)

Gerbens-Leenes PW, Van Lienden AR, Hoekstra AY, van der Meer TH (2012) Biofuel scenarios in a water perspective: the global blue and green water footprint of road transport in 2030. Glob Environ Chang 22:764-775

Gerbens-Leenes PW, Mekonnen MM, Hoekstra AY (2013) The water footprint of poultry, pork and beef: a comparative study in different countries and production systems. Water Resour Ind $1-2: 25-36$

Hoekstra AY (ed) (2003) Virtual water trade. In: proceedings of the international expert meeting on virtual water trade, delft, The Netherlands, 12-13 December 2002. http://www.waterfootprint. org/Reports/Report12.pdf

Hoekstra AY, Chapagain AK (2007) Water footprints of nations: water use by people as a function of their consumption pattern. Water Resour Manag 21(1):35-48

IAASTD (International Assessment of Agricultural Knowledge, Science and Technology for Development) (2008) Agriculture at a crossroads: global report. IAASTD, Island Press, Washington

Karrou M, Oweis T, Benli B, Swelam A (2011). Improving water and land productivities in irrigated systems. Community-based optimization of the management of scarce water resources in agriculture in CWANA Report no. 10. International Center for Agricultural Research in the Dry Areas (ICARDA), Aleppo, Syria, pp. +195

Khan BB, Iqbal A, Riaz M (2003) Production and management of camels. Department of Livestock Management, University of Agriculture, Faisalabad

Mekonnen MM, Hoekstra AY (2010) The green, blue and grey water footprint of farm animals and animal products. Volume I: Main
Report, Value of Water Research Report Series No. 48, Delft, The Netherlands

Mekonnen MM, Hoekstra AY (2011) The green, blue and grey water footprint of crops and derived crop products. Hydrol Earth Syst Sci 15:1577-1600

Mekonnen MM, Hoekstra AY (2012) A global assessment of the water footprint of farm animal products. Ecosystems 15(3):401-415

Missimer TM, Guo W, Maliva RG, Rosas J, Jadoon K (2014) Enhancement of Wadi dam recharge using dams coupled with aquifer storage and recovery wells. Environ Earth Sci 73(12):7723-7731

Molden D, Oweis T, Steduto P, Bindraban P, Hanjra MA, Kijne J (2010) Im- proving agricultural water productivity: between optimism and caution. Agric Water Manag 97:528-535

MOWE (Ministry of Water and Electricity) (2013) Annual report Riyadh, Saudi Arabia. http://www.mowe.gov.sa/ENIndex.aspx. Accessed May 2014

Ouda OKM (2014) Impacts of agricultural policy on irrigation water demand: case study Saudi Arabia. Int J Water Resour Dev 30(2):282-292

Papadopoulou MP, Charchousi D, Tsoukala VK, Giannakopoulos Ch, Petrakis M (2016) Water footprint assessment considering climate change effects on future agricultural production in mediterranean region. Desalination Water Treat 57(5):2232-2242

Ran YM et al (2016) Assessing water resource use in livestock production: a review of methods. Livest Sci 187:68-79

Rockström J, Falkenmark M, Folke C, Lannerstad M, Barron J, Enfors E, Gordon L, Heinke J, Hoff M, PahlWostl C (2014) Water resilience for human prosperity. Cambridge University Press, NY

Rost S, Gerten D, Bondeau A, Lucht W, Rohwer J, Schaphoff S (2008) Agricultural green and blue water consumption and its influence on the global water system. Water Resour Res 44(9):1-17

Shiklomanov IA (2000) Appraisal and assessment of world water resources. Water Int 25(1):11-32

SSYB (Saudi Statistical Year Book) (2011) Saudi statistical year book. http://www.cdsi.gov.sa/yb46/Pages/MixFPage.htm

Steinfeld H, Gerber P, Wassenaar T, Castel V, Rosales M, de Haan C (2006) Livestock's long shadow: environmental issues and options. FAO, Rome, p 390

UNDP (United Nations Development Programme) (2013) Water governance in the Arab region: managing scarcity and securing the future. UN Plaza, New York 10017, USA

USDA (2016) Saudi Arabia: Grain and Feed Annual. GAIN Report No. SA1602. https://gain.fas.usda.gov/Recent/GAIN/ Publications/GrainandFeedAnnual_Riyadh_SaudiArabia_3-142016.pdf

World Bank (2010) Making the most of scarcity: Accountability for better water management results in the Middle East and North Africa Report, Washington. USA

\section{Publisher's Note}

Springer Nature remains neutral with regard to jurisdictional claims in published maps and institutional affiliations. 